\title{
The Structure of Madinah's State, A Study from the Prophet Muhammad (PBUH) Seerah
}

\author{
*Dr. Fazle Omer \\ *D. Dr. Farhadullah \\ *** Dr. Naseem Akhter
}

\section{ABSTRACT:}

Hazrat Muhammad (PBUH) being the last the final Prophet, was sent as a source of absolute kindness and mercy to the whole of humanity. His life after prophet hood is divided into two phases i.e. Makki and Madani. The former is mainly concerned with preaching of monotheism while the latter was the busiest phase of his life having crucial importance in framing an absolute example for his followers till the last day. Madani phase is consisted upon ten years, in which the Prophet (PBUH) performed multiple duties of preaching, negotiation, reformation, defense, education, instruction, reconciliation, leadership and Heading a state. The holy Prophet (PBUH) established the first Islamic state in Madinah in which he acted dual role of heading the state as well as the Government, simultaneously.

In the current paper, the anatomy and characteristics of the first Islamic state will be elaborated in order to give an insight for adorning the present system with its qualities for providing a perfect model of an Islamic welfare state.

Keywords: Seerah, Islamic State, Leadership, preaching, negotiation.

\section{Introduction:}

The institution of state as a politically organized community is found throughout the human history. The Greeks called it "polis" and the ancient Romans called it "civitas". The Romans also used another term, namely "Status re publica". The Latin word "status" became "stato" Italian in the middle ages. In French it became "State", in English "State" and in German "Staat".

A modern sociological writer "Maclever" defines the state as "an association which, acting through law as promulgated by a government, endowed to this end with coercive power, maintains with community territorially demarcated the universal external conditions of social order. ${ }^{2}$

While another social scientist Harold J. Laski defines the state as "a territorial society divided into government and subjects claiming within its allotted physical area, supremacy over all institutions. Thus, Laski also emphasizes the

\footnotetext{
"Visiting Lecturer KMU Institute of Medical Sciences, Kohat, KPK.

Email: dr.farhadullah@kust.edu.pk

${ }^{* *}$ Assistant Professor, Kohat University of Science \& Technology, Kohat.

${ }^{* * *}$ Assistant Professor, Islamic Studies, Shaheed Benazir Bhutto Women Uni: Peshawar.
} 
four-element constituting the state i.e. (i) Society or People, (ii), Territory or an allotted physical area, (iii). Government and (IV). Supremacy or Sovereignty. ${ }^{3}$ A Muslim political scientist Dr. Taima Al-Jarf says that the state is: "a group of individuals who live a stable and permanent life on a given territory under a particular political organization that allows some members of the state to challenge the rule of others. ${ }^{4}$

From the above-mentioned definitions of the state, it is learnt that state is composed of four essential elements or attributes, which are as under:

\section{1: Population. 2: Land or Territory. 3: Government. 4: Sovereignty.}

The former two elements are the physical bases of the state while the latter ones are the political or spiritual bases, respectively.

The anatomical and structural study of state of Madinah reveals that above described four elements were fully existent in its formation.

1: People living in Madinah and its surroundings amounted to its population

2: The area of Madinah and surroundings became its geographical territory

3: A government was established who was headed by the Prophet himself

4: The absolute power of sovereignty granted to Almighty Allah.

Hence, it is proved that Madinah was a perfect state which contained all necessary elements of the state which are considered necessary in contemporary modern sense of political science.

The religion of Islam and institution of state/government are like twins which runs abreast. Islam is like a building and government is like its mentor or supervisor. A building which does not has sound foundations shall collapse soon. Similarly, a building which is not protected, shall be looted. In an ideal Islamic state, a balance system of social justice prevails. The state rules over the entire human life, it is neither dictatorship nor autocracy rather it is a welfare which continuously work for the welfare of its citizens. The central point of all state institutions is the establishment of God's supremacy and sovereignty on the earth. The Muslim ruler work as "khalifa" (a caliph or representative) of God, who provides conducive environment for implement-tation of God's commands.

Each and every Muslim believes that Prophet Muhammad (PBUH) is the wisest and noblest person of the world. His life has been declared as "اسوة حسنت which stands for a perfect model to be followed. The life of the Prophet (PBUH) is divided into two phases i.e. Makki and Madani. Makki life denotes the tenure of his life spent before the incident of Hijra (migration) to Madinah. While the Madani life the is taken for the tenure of his life spent after Hijrah. Both the phases are equally important in the study of the biography of the Prophet (PBUH). The former laid foundation for the later on which, subsequently, the building of 
Islam was erected. The Holy Prophet (PBUH) spent thirteen years in Makkah and spent ten in Madina Munawwara after he was granted with prophet hood. ${ }^{5}$ Whereas the case of concept of state is concerned in seerah, a researcher finds the details in the Madani span of life.

The Holy Prophet (PBUH) being the head of the first Islamic state took over the great responsibility of preaching and performed his role perfectly in various courses. Being a prophet, He was the vicegerent of Almighty Allah who was heading a state. At the same time, he was the commander of Islamic army, the judge who was delivering justice and an economist who was supervising the financial matters of the state. He reorganized the scattered human society on natural footings and gathered them under single authority.

Anatomy of State in the time of the Prophet (PBUH):

Before migration of the Prophet Muhammad (PBUH) to Madinah, there was no civic or organized political system in the city. There were two main tribes living in the city of Madinah i.e. Aus and Khazraj which were rival to each other. They used to fight with one another. When Prophet (PBHU) arrived in the city, he organized a proper political system through consultation with all stake holders. Both the rival tribes agreed on the leadership of the Holy Prophet (PBUH) which laid the very first foundation of Islamic state which, afterwards, turned into the capital of a large Islamic sultanate. ${ }^{6}$ In this state, non-Muslim were granted full religious freedom: ${ }^{7}$

"Muslim shall follow their own religion and Jews shall follow theirs".

The state of Madinah can be divided into following institutions:

\section{1: The Head of state:}

The Prophet Muhammad (PBUH) was the Head of state/government.

\section{2: Judiciary:}

The Holy Prophet (PBUH) performed duties of delivering justice to the Muslims as well as Non-Muslims.

\section{3: Defense:}

The Holy Prophet (PBUH) was the Chief of Armed forces.

\section{4: Preaching, Education and Reforms:}

The Holy Prophet's (PBUH) prime duty was preaching the Islam. He was the Master/Chief Educator.

\section{5: Diplomacy:}

The Holy Prophet used to send diplomats to neighboring tribes and states.

\section{6: Finance:}

The Holy Prophet established a financial system based on economic justice and uprightness without any external compulsion. People were encour-aged to spend 
voluntarily on their relatives, orphans, captives, prisoners, passi-ngers and poor. People were stimulated to earn halal sustenance and feed others. Zakat was obligated upon Muslims and proper system was devised for its collection and distribution. E.g. Huzaifa bin Yaman (RA) was responsible for calculation of zakat on fruit items. He was also directed to keep written record of all collections. ${ }^{8}$

\section{Characteristics of the State of Madinah:}

\section{1: The Concept of the Sovereignty:}

In any political system or government policy, the very first question is fixing the ultimate source of sovereignty. Different political systems have devised this source according to their particular political theories or religious dogmas. Whereas the case of Islam is concerned, the Holy Prophet (PBUH) proclaimed from the beginning that absolute and ultimate power of sovereign lies with the Almighty Allah. The Holy Quran says:

\section{2: $\quad$ Consultation based system:}

The political system introduced by the Prophet Muhammad (PBUH) was based on mutual consultation with his companions. All major issues were used to settle with the discussion in a meeting. In the campaign of the Ahzab, the decision of digging a moat was made with consultation of the companions. The Prophet Muhammad (PBUH) developed trust and confidence among his followers through conferencing with them. Some specimens are as under:

a. Consultation about Azan ${ }^{10}$

b. Consultation about campaign of $\mathrm{Badr}^{11}$ (2 Hijri)

c. Consultation about prisoners of $\mathrm{Badr}^{12}$

d. Consultation about Mazbin-Jabal regarding his governorship in Yemen ${ }^{13}$ 1: A reformative society:

It is an undeniable fact that any state or government gets discipline and organization when all social, moral and economical evils are controlled. The Holy Prophet (PBUH) tried his best to curb all such evils in order to provide an organized society for smooth governance.

\section{2: $\quad$ Piety and fearing of God:}

Piety is the sole root of all good deeds. The Holy Prophet (PBUH) and his Companions were fully adorned with this prestigious quality of Islamic faith. He used to advise his followers to always remain intact with this quality. Once, he pointed to his heart three times and said to his companions:

$$
\text { 14،"Piety is right here (in the heart)"'التقوئ ههنا" }
$$

\section{3: Propagation of religion:}

Propagation of Islam retains pivotal point in the organization and disciplining 
of state. For this purpose, the Holy Prophet made efforts for the dissemination of Islamic teachings. Resultantly, the religion of Islam spread rapidly.

\section{4: $\quad$ The Prophet (PBUH) as Practical example:}

One of important teachings of religion of Islam is:

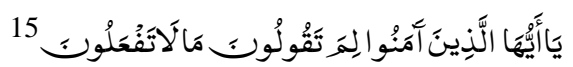

“O’ believers, why do you say what you do not do?"

The Holy Prophet (PBUH) was a real and practical example of what he used to preach and instruct to his followers. He implemented each and every command of Almighty Allah perfectly and presented a role model for whole of the humanity.

\section{5: Rule of law:}

The state of the Prophet (PBUH) was enriched with the Rule of Law. All citizens of this state were equal before the law. There was neither discrimination nor privilege. The Holy Prophet (PBUH) was directed to follow the revaltion of Almighty Allah: ${ }^{16}$

"So, judge between them by what Almighty Allah has revealed and don not follow their inclinations".

\section{6: Equality}

The Holy Prophet (PBUH) founded his state on the sound foundation of "Equality and Equity" without any decimation of color, tribe, religion and language. All members of the society were equally enjoying their rights. The Holy Prophet (PBUH) declared: ${ }^{17}{ }^{17}$

"The People are all the children of Adam, and Adam was created from dust".

\section{7: $\quad$ Transparency}

The notion of transparency has been disclosed in the Holy Quran by Almighty Allah as under:

'O' you, who believe, when you deal with each other in transaction involving future obligations in a fixed period of time, reduce them to writing. Let a scribe write down faithfully as between the parties". ${ }^{18}$

In the state of Madinah, the characteristic transparency was blooming in every sphere of state's functions. All matters used to settle and decide with mutual consultation in public place of Masjid Nabawi. There was zero tolerance for corruption and money making. It is narrated that:

"Allah's Messenger (PBUH) appointed a man called Ibn Al-Lutabiyya to collect the Zakat from Bani Sulaim's tribe. When he returned, the Prophet (PBUH) called him to account. He said (to the Prophet, 'This is your money, and this has been given to me as a gift." On that, Allah's Messenger said, "Why 
didn't you stay in your father's and mother's house to see whether you will be given gifts or not if you are telling the truth?"19

\section{8: $\quad$ Freedom/Privacy}

Freedom identifies a condition in which human beings can act according to their own free will and take responsibility of their actions. Freedom of opinion, freedom of religion and freedom expression is provided to every citizen. In the Islamic state of Madinah, Non-Muslims were given full freedom to practice their own religion freely. Even, the Non-Muslims were so confident that they used to bring their issues for settlement to the Prophet (PBUH). Similarly, Privacy of every person is guaranteed in the Islamic teaching. People are warned to avoid spying others. The Quran says categorically that "There is absolutely no compulsion or coercion in (opting for a particular) Deen (or a way of life or a system of beliefs and actions)". The Holy Quran maintains:

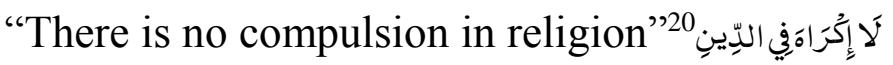

\section{9: Accountability}

In Arabic, the term "ihtesab" is used for accountability which is derived from the word "hesab". The same is repeated in the Holy Quran more than eight times in various verses. Every Muslim believes in accountability as all humans will be judged for whatever they used to do in the world.

The Holy Prophet (PBUH) used to supervise and check various matter of the state himself. On the other hand, he also appointed some of his companions on major administrative duties. He used to visit the markets in order to check the fairness in business and issue necessary instructions on the spot. Similarly, violators had to face punishments and reprimands.

\section{0: Justice}

Delivery of the Justice is regarded as the most important pillar of the state In Islam. The Holy Quran uses the terms of "عدل و قسط" for the justice. The Holy Prophet (PBUH) practically confirmed that no one is above the law of God. The Holy Quran advises:

“'O' you who believe! Stand out firmly for justice, as witnesses to Allah, Even though it be against yourselves, or your parents, or your kin". ${ }^{21}$

\section{Comparison of Good Governance indicators with State of Madinah:}

The United Nations Educational, Scientific and Cultural Organization (UNESCO) has adopted system for measuring the good governance and the following are some principles of good governance: ${ }^{22}$

\section{1: Participation:}

Participation is a crucial key of good governance. It means the participa-tion of public in decision making process. It brings transparency and provides help in 
adapting the decision according the needs of the public. The study of seerah of the Prophet (PBUH) reveals that he used to participate his fellow Muslims through consultation. Following are some examples of consultation for participation:

\section{2: Human Rights:}

All human beings have certain basic inherent and inalienable rights to which they entitled by birth but, generally, the situation of human rights has not been encouraging in human history. Whereas the case of the Madinah's state is concerned, one can say that the term of Human Rights is inadequate to describe its best condition as human as well as animals were granted basic rights.

\section{3: $\quad$ Rule of Law}

Rule of Law means the supremacy of law and judicial system within a particular society.It's fundamental to stability and smooth functioning of society. The rule of law depends on the independent and honest policing and judiciary.

\section{4: Anti-Corruption, Transparency and Accountability}

Corruption is the serous issue which is facing by states throughout the human history. Corrupt practices rob governments of means to ensure good life their public and erode their legitimacy.

\section{5: Access to information}

Access to information means that public should have the right to know government's affairs, expenditures and policies. They should have the right to raise objection on any irregularity. This characteristic ensures greater participation of public in governance. This allows maximum verifiability of information and allows all stakeholders to come to table equally on important issues.

\section{6: Poverty Reduction:}

Poverty is a combine issue of the world including developing and developed countries. Poverty reduction means to adopt measures for lifting the poverty on permanent basis through human and economic factors. The eradication of poverty is indeed a vital condition for global stability, democracy and peace. As long as the poor are excluded from participation in global growth, sustainable peace and development will remain out of reach.

\section{7: $\quad$ Governance of Media}

Media is a bridge of information between the government and public. In the modern world, media, (print, electronic or and social) is vital for flourishing democracy in the world. A positive relationship between government and media is necessary for nourishing an independent and pluralistic Medias cape. The control of media also includes the diversion of governance among the different sectors.

\section{Discussion:}

When one compares these indicators with the Islamic State of Madinah, he finds 
that almost all these indicators of good governance were present in the Islamic state centuries ago except the last one because the Media (print, electronic\& social) are the inventions of the present modern age. Study of the seerah proves this claim, which is stated in the table mentioned below:

\begin{tabular}{|r|l|c|}
\hline S.No & \multicolumn{1}{|c|}{ Indicator's Specification } & Presence in State of Madinah \\
\hline 1. & Participation & $\sqrt{ }$ \\
\hline 2. & Human Rights & $\sqrt{ }$ \\
\hline 3. & Rule of Law & $\sqrt{ }$ \\
\hline 4. & Anti-Corruption, Transparency & $\sqrt{ }$ \\
\hline 5. & Access to information & $\sqrt{ }$ \\
\hline 6. & Poverty Reduction & $\times$ \\
\hline 7. & Governance of Media & $\times$ \\
\hline
\end{tabular}

\section{Suggestions:}

1: $\quad$ Revival of original Islamic belief/creed among Muslims. They should be confident upon the teaching and instructions of the Prophet Muhammad (PBUH) and they should not consider them outdated for the modern age.

2: $\quad$ Refreshing the conscious: Unconsciousness in considered as a death for a particular nation. Muslims' conscious is very weak in the fields of civics, rationale and culture. They are heavily inspired by the West. Refreshing and training of conscious is direly needed.

3: Selfishness should be avoided at all costs. Islam is a collective religion, which demands welfare of all human beings. Even Non-Muslims used to feel secure and satisfied in the Islamic states in the past. Therefore, the collective benefits should be preferred upon single ones.

4: $\quad$ Industrial and technological advancement should be acquired rapidly in order to end reliance upon others. This will make Muslims confidant and will empower them to play active impressive role in the global politics.

5: Academic restructuring is required to attain leadership in knowledge and science same like the past. Getting rid of colonial influences is necessary for academic restructuring on modern footings. Research, innovation and quality publications need to be expedited. Academic leader should equally be equipped with true Islamic spirit along with relevant expertise.

\section{Summary:}

The spirit of all Islamic instructions is the foundations of God's sovereignty on the earth. This goal cannot be achieved with subjugation of society under the Islamic instructions. The Holy Prophet established the very first Islamic state in the Madinah which later on, became the center of the Islamic world. This state 
was headed by the Prophet himself and provided a perfect example for the whole humanity in the administrative, judicial and welfare matters. The modern indicators of good governance also prove that this state was a unique model of ruling 1400 years ago. It is necessary for the Muslims to follow the instructions of Islam in true sense with utmost confidence for providing a practical example of good governance. Academic and Technological advancement is direly needed for the Muslim for their active impressive role on global forums.

\section{References:}

${ }^{1}$ Haque, Mazhar Ul, Political Science Theory and Practice, Lahore, Book Land Publishers, 1993, p.109

${ }^{2}$ Maclever, R.M, The Modern State, University Press of the Pacific, 2001, p.22

${ }^{3}$ Laski, H.J., A Grammar of Politics, George Allen\& Unwin Ltd, London, 1925, p.21

${ }^{4}$ Al-Jarf, Dr. Taima, Nazmul Hukum, Dar Al-Nahda, Cairo, 1978, p.76

${ }^{5}$ Ibn-e-Khateer, Al-BidayaWa Al-Nihaya,MaktabatulMaarif, Beirut,2014, vol. 3, p.4

${ }^{6}$ Hamidullah, Dr, KhutbatBahawalPur, Islamic Research Institute, Islamabad,2009, p.204

${ }^{7}$ Mubarkpuri, Safiurrehman, Al-Raheeq Al-Makhtoom, Beirut DarulHilal, p.173

$$
\text { ألصعيدى، عبدالهتعال، السياسة الاسلاميتفى عهد النبوة، قاهره،دارالفكر، طبعثانى، }
$$

${ }^{9}$ Al-Quran30:04

$$
\text { 10 }{ }^{10}
$$

${ }^{11}$ Ibid, p.267

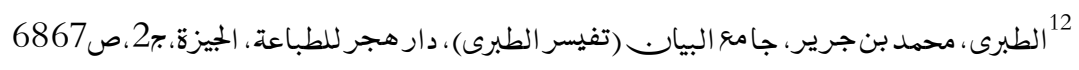

${ }^{13}$ Ansari, Molana Hamid, Islam kaNizameHukoomat, Al-Faisal Publishers, Lahore,2015, p.42

${ }^{14}$ Sahih Muslim, Qadeemi Kutub Khana, Karachi, 1978, Hadith No. 2564

${ }^{15}$ Al-Quran61:02

${ }^{16}$ Al-Quran05:48

${ }^{17}$ Sunan Tirmizi ,Maktaba Rahmania, Lahore, 2008, chapter 49, Hadith No.4336

${ }^{18}$ Al-Quran02:282

${ }^{19}$ Sahih Al-Bukhari, Qadeemi Kutub Khana Karachi, 1978, Hadith No. 6979

${ }^{20}$ Al-Quran02:256

${ }^{21}$ Al-Quran04:135

${ }^{22}$ Khan, Dr.Sultan, Good Governance \& Public Policy, Famous Books Lahore, pp.48-50

\section{(9) (1)}

This work is licensed under a Creative Commons Attribution 4.0 International License. 